\title{
The potential of frozen rumen fluid for ruminant feed evaluation using in vitro gas production technique
}

\author{
Melyndra Sonya Pramita and Hendrawan Soetanto* \\ Faculty of Animal Science, Universitas Brawijaya, Malang 65145, Indonesia
}

\begin{abstract}
The aim of this study was to determine the potential of frozen rumen fluid (RF) for ruminant feed evaluation using in vitro gas production (IVGP) technique. This study used a factorial randomized block design with a $3 \times 3 \times 3$ pattern, consisting three feeding regimes varying in forage to concentrate proportion, namely $20 \%: 80 \%$ (feed A), $40 \%: 60 \%$ (feed B), and $60 \%: 40 \%$ (feed C), respectively; three storage time (2, 11 , and 19 days); and RF from 3 breeds of indigenous cattle, namely Bali, crossbred Ongole and Madura cattle as groups. The results showed that the effects of feeding regimes, inoculum source, or storage time on total gas production, potential of gas production, rate of gas production, dry matter and organic matter degradability. Based on the results, it can be concluded that frozen RF may be used as inoculum source for feed evaluation using the IVGP technique and hence it supports the previous findings reported in the literature. Considering that the effects of different feeds, inoculum sources, and storage times gave the specific values, it is advisable that to use RF from slaughtered animals should be taken from the same breed to allow accurate comparison for feed evaluation using IVGP technique.
\end{abstract}

\section{Introduction}

The in vitro gas production (IVGP) technique has been widely applied as a routine feed evaluation for ruminant animals in many countries. By recording the gas at several time intervals, the kinetics of rumen fermentation can be measured [1] and the values of feed digestibility calculated correlate very strongly with the values obtained by in vivo digestibility measurements. [2]. It therefore, is understandable if the IVGP technique becomes more preferred than in vivo digestibility measurement that is more tedious, capital, and time-consuming.

The application of the IVGP technique, unfortunately, requires the use of rumen fluid as microbial inoculum from rumen cannulated animals that pose questions on the compliance of animal welfare [3,4] This recent pressure on the ban of cannulated animals for such researches has encouraged researchers to seek other alternatives. A number of reports are available in the literature on the use of ruminant's faeces such as cattle and sheep as a source of inoculum $[5,6,7]$, but the digestibility values obtained are generally lower which is

* Corresponding author: hendrawan07@ub.ac.id 
attributable to the lower population of rumen microbes in the faeces [8] RF can also be collected by inserting a stomach tube via the mouth of animals, however RF may be contaminated with saliva and fluid exchange with the omasum and abomasum [9]. The alternative source of RF as microbial inoculum that is abundantly available is from slaughtered animals at the abattoir or in some instances it is available in a particular religious festival time such as Eid al-Adha in the Muslim-populated countries like Indonesia where the practice of sacrifice takes place during three days of festival by slaughtering ruminant animals.

The problem that often arises in the use of RF from slaughtered cattle is ignorance of the prior feed consumed by livestock before being slaughtered which may affect the extent of gas production during the course of studies. Another mitigating question is the feasibility usage of frozen RF for IVGP studies. Several studies had reported the agreement in gas production using fresh RF from slaughtered cattle as compared with frozen RF even though some precautions require judicious attention. Recently, [11] reported their study on the use of frozen RF for IVGP and concluded that stored RF up to 72 hours had no significant decrease in gas production, but it declined after 96 hours of storage. This notion opens for further studies on the possibility of using cryoprotectants such as dimethyl sulfoxide (DMSO) or glycerol [12] to improve the longevity of rumen microbes during the frozen phase. The existence of the majority of Indonesian people who are Muslim strongly supports the implementation of this alternative because there is an Eid al-Adha, where many ruminants are slaughtered simultaneously. It can be used to compare the yield of feed fermentation carried out by rumen microbes of different livestock breeds.

Quality of feed greatly affects the yield of rumen fermentation and it is the reason why the low quality of tropical forages seldom meets the nutrient requirement of ruminants to support their genetic potential. Therefore, it is important to add concentrates to correct the nutrient imbalance for this particular objective. The proportion of forage to concentrate in the diet mostly used by breeders in Indonesia is $60 \%: 40 \%$, but it may change up to $20 \%: 80 \%$ for fattening cattle. Involving the proportion of concentrate in feed up to $100 \%$ can increase the degradability of dry matter from $75.03 \mathrm{~g} / 100 \mathrm{~g}$ DM to $88.85 \mathrm{~g} / 100 \mathrm{~g}$ DM [13], but this practice may impose some disadvantages, namely economically inefficient and lowering the rumen $\mathrm{pH}$ that leads to acidosis, a type of digestive disturbance. This study aimed at elucidating the feasibility of using frozen RF taken from slaughtered cattle to evaluate three cattle feeds varying in the proportion of forage to concentrate by the IVGP technique.

\section{Materials and Methods}

\subsection{Experimental Location and execution}

The research took place from August to October 2020 at the Laboratory of Animal Nutrition and Feed, Faculty of Animal Science, Universitas Brawijaya.

\subsection{Materials}

A complete feed consisting of grass hay and commercial concentrate was used in this study. The hay was a mixture of signal grass (Brachiaria decumbens) and star grass (Cynodon plectostachyus) obtained from Artificial Insemination Centre (Singosasi, Malang) while concentrate was obtained from a local feed market. 


\subsection{Methods}

This study used a factorial randomized block design with a $3 \times 3 \times 3$ pattern. Three feeding regimes varying in the forage : concentrate ratio, namely $20 \%: 80 \%$ (feed A), $40 \%: 60 \%$ (feed B), and 60\%: 40\% (feed C), respectively as the first factor. The RF was stored in the deep freezer at $-25^{\circ} \mathrm{C}$ for 2,11 , and 19 days as the second factor. RF extracts from three different breed were used as a group in the design.

\subsubsection{Sample preparation}

Each feed sample was taken as much as $1 \mathrm{~kg}$ and oven-dried at $60^{\circ} \mathrm{C}$ to obtain air-dry matter content. The dried sample was then mashed with a grinder through a $1 \mathrm{~mm}$ sieve for further use and stored in plastic clips. Feed samples were analysed for proximate nutritive values [14] of dry matter (DM), organic matter (OM), crude protein (CP), ether extract (EE), and crude fibre (CF). Table 1. below describes the chemical composition of three feeding regimes

Table 1. Chemical composition of feed treatments

\begin{tabular}{|c|c|c|c|c|c|}
\hline \multirow{2}{*}{$\begin{array}{c}\text { Feeding } \\
\text { Regime }\end{array}$} & \multicolumn{5}{|c|}{ Chemical Composition (\%) } \\
\cline { 2 - 6 } & DM & OM & CP & CF & EE \\
\hline A & 82.94 & 91.78 & 14.34 & 15.68 & 5.75 \\
\hline B & 82.08 & 92.04 & 11.67 & 22.08 & 3.71 \\
\hline C & 81.18 & 91.95 & 8.79 & 28.25 & 3.48 \\
\hline
\end{tabular}

Based on \%DM

\subsubsection{Collection of rumen digesta}

Rumen digesta was taken from 3 breeds of cattle that were slaughtered for the Islamic festival of Eid al-Adha $1441 \mathrm{H}$ (31 July 2020 and 1 August 2020) within the regency of Malang. The traveling time from the onset of rumen digesta collection to reach the nutrition laboratory varied between 18 - 50 minutes. The detailed information of the sampling location is presented in Table 2.

The rumen digesta of the respective cattle breed was immediately taken after the rumen was opened, checked for the temperature, and squeezed gently while transferred into the prewarmed flasks until full and closed with the lid. They were then transported to the Nutrition and Feed Laboratory for further process.

\subsubsection{Preparation of inoculum}

As soon as arrived in the laboratory, all rumen digesta was emptied from the flasks and transferred into plastic bottles, and stored in the freezer at $-28^{\circ} \mathrm{C}$. The contents of the rumen of each cattle breed were transferred into 5 plastic bottles with a capacity of $330 \mathrm{ml}$. The rumen digesta in the flask was poured into a plastic bottle and mixed between respective cattle breed under continuous flushing with $\mathrm{CO}_{2}$ prior to be sealed with a metal cap and stored until required. 
Table 2. Information on the distribution site for RF intake

\begin{tabular}{|l|l|l|c|c|c|}
\hline $\begin{array}{c}\text { Cattle } \\
\text { Breed }\end{array}$ & Pick Up Date & \multicolumn{1}{|c|}{ Location } & $\begin{array}{c}\text { Distance for } \\
\text { Location to } \\
\text { Laboratory } \\
(\mathbf{k m})^{*}\end{array}$ & $\begin{array}{c}\text { Duration for } \\
\text { transport } \\
\text { (minute) }\end{array}$ & $\begin{array}{c}\text { No. of Cattle } \\
\text { (head) }\end{array}$ \\
\hline \multirow{2}{*}{ PO } & 31 July 2020 & Pujon Sub-district & 29 & 51 & 1 \\
\cline { 2 - 7 } & $\begin{array}{l}1 \text { August } \\
2020\end{array}$ & $\begin{array}{l}\text { Moslem Boarding } \\
\text { School Sabilurrosyad } \\
\text { Gasek village, } \\
\text { Malang Regency }\end{array}$ & 3.4 & 10 & 2 \\
\hline Madura & $\begin{array}{l}1 \text { August } \\
2020\end{array}$ & $\begin{array}{l}\text { Tlogomas Village, } \\
\text { Lowokwaru sub- } \\
\text { district Malang City }\end{array}$ & 5.8 & 13 & 3 \\
\hline \multirow{2}{*}{ Bali } & $\begin{array}{l}1 \text { August } \\
2020\end{array}$ & $\begin{array}{l}\text { Wiagan Sekarpuro } \\
\text { village, Pakis sub- } \\
\text { district Malang City }\end{array}$ & 8.8 & 18 & 3 \\
\hline
\end{tabular}

*) Information was obtained from Google Map

\subsubsection{Thawing procedure}

The bottle containing the contents of the rumen was thawed first using pre-warmed water $39^{\circ} \mathrm{C}$ for \pm 30 minutes. After the thawing process was done, the contents of the rumen in the bottle were filtered using a three-layered filter cloth and measured as needed. The source of inoculum from one breed of cattle was taken from three heads, so that the RF requirement per cattle was $1 / 3$ part of the total $R F$ requirement in one solution formula.

\subsubsection{In vitro gas production analysis}

The technique of IVGP has been described by Soetanto et al [15] and the procedure is briefly as follows. A $500 \mathrm{mg}$ of feed representing respective feeding regimes was inserted into a 100 $\mathrm{ml}$ glass syringe according to [16]. The syringe was incubated overnight before being used for in vitro analysis. In the in vitro test, the solution is added to the syringe, with a solution formula consisting of $1095 \mathrm{ml}$ distilled water, $730 \mathrm{ml}$ buffer solution, $365 \mathrm{ml}$ macro-mineral solution, $0.23 \mathrm{ml}$ micro-mineral solution, $1 \mathrm{ml}$ resazurin, $60 \mathrm{ml}$ freshly prepared reductive solution, and $660 \mathrm{ml}$ of RF. A syringe without a sample was included in the incubation process as a blank, to correct the production of the gas produced. The syringes were incubated in a water bath at $39^{\circ} \mathrm{C}$ for 48 hours. Gas production at $2,4,6,8,10,12,18,24,36$, and 48 hours incubation was recorded to allow the kinetic of respective gas production was calculated. Meanwhile, the potential and rate of gas production were calculated by the equation according to [16] as follows, $\mathrm{Y}=\mathrm{b}\left(1-\mathrm{e}^{-\mathrm{ct}}\right)$, where $\mathrm{Y}$ : gas produced at the time ' $\mathrm{t}$ ' $(\mathrm{ml} / 500 \mathrm{mg} \mathrm{DM}), \mathrm{b}$ : the potential of gas production $(\mathrm{ml} / 500 \mathrm{mg} \mathrm{DM})$, c: rate of gas production $(\mathrm{ml} /$ hour), t: incubation time (hour), and e: exponential.

\subsubsection{Rumen degradability}

Rumen degradability was calculated gravimetrically according to the tare DM or OM weight of the original sample minus residue. The remaining residue from the gas production was transferred to the tube and was centrifuged at $1409 \mathrm{~g}$ for 5 minutes until the supernatant was clear and then discarded. The sediment was transferred to the crucible and oven-dried at 105 ${ }^{0} \mathrm{C}$ and weighted to obtain feed degradation in the rumen. The dried sediment was then burned at $550^{\circ} \mathrm{C}$ to measure the $\mathrm{OM}$ content of the sediment for further calculation of $\mathrm{OM}$ 
degradation. This procedure refers to [16] which was modified according to the laboratory conditions in this study.

\subsubsection{Statistical analysis}

This study used a factorial randomized block design with a $3 \times 3 \times 3$ pattern. If the results of the design show no interaction between factors, each factor was tested using a randomized block design to determine its effect on individual factors [17]. The data obtained were tabulated using Microsoft Excel 2016. While the potential and rate of gas production were obtained by the NEWAY method using Microsoft Excel 2016. If the data in ANOVA showed differences due to treatment, it was continued by a Duncan's Multiple Range Test.

\section{Results and Discussion}

Table 3 summarizes the statistical analysis of all parameters measured during the IVGP study and clearly demonstrated that there was no significant decrease $(\mathrm{P}>0.05)$ as the storage time increased from 2 to 19 days. Furthermore, the interaction among feeding regimes, source of inoculum, and storage time of RF also revealed no significant difference $(\mathrm{P}>0.05)$. In accordance with [18], as there is no interaction between feed, source of inoculum, and storage time, further statistical analysis was done to the main effects, namely feed, source of inoculum, and storage time only.

As shown in Table 4, There is variation in results among the main effects of feed, inoculum sources, and storage time in the respective cattle breed. The effect of feed on storage time is presented in Table 4. Storage time of RF for 2 days showed a highly significant difference $(\mathrm{P}<0.01)$ on total gas production, gas production rate, and OMD. Storage time of RF for 11 days showed a highly significant difference $(\mathrm{P}<0.01)$ in the total gas production and the rate of gas production. Meanwhile, the storage time for 19 days showed a significant different $(\mathrm{P}<0.05)$ on gas production and gas production potential, as well as a very significant different $(\mathrm{P}<0.01)$ on the rate of gas production.

The effect of feeding regime on the inoculum source is presented in Table 5. The inoculum source of $\mathrm{PO}$ and Madura cattle showed a highly significant different $(\mathrm{P}<0.01)$ on both the total and rate of gas production. Meanwhile, the inoculum source from Bali cattle showed a very significant different $(\mathrm{P}<0.01)$ on the rate of gas production and DMD, and had a significant different on total gas production $(\mathrm{P}<0.05)$.

Table 6 describes the effect of storage time on the inoculum source. PO cattle RF showed a very significant different $(\mathrm{P}<0.01)$ on total gas production and gas production rate, the use of Madura cattle RF also showed a significant different $(\mathrm{P}<0.05)$ on total gas production. Meanwhile, Bali cattle RF showed a very significant different $(\mathrm{P}<0.01)$ on DMD and OMD, as well as a significant different $(\mathrm{P}<0.05)$ on the rate of gas production.

Sources of inoculums obtained from different breeds of cattle indicate that there are differences in the diversity of life in the rumen which can be influenced by the type or species of the host itself, physiological status, and age of the cattle [19, 20, 21]. Information on these factors is not recorded, because the origin of livestock raising prior to slaughter is not known certainty. In addition, the feed consumed can affect the abundance of rumen microbes. The feed will be hydrolysed by rumen microbes through the enzyme activity they produce by attaching the rumen microbes to the feed particles. This is the most efficient way for microbes to prolong their residence in the rumen and carry their enzymes to adhere to other substrates [22].

Gas production describes the products produced from rumen microbial fermentation. Gas production from three feed treatments given showed the highest value in feed A. The high gas production during the 48 -hour incubation was in line with the increasing proportion of 
concentrate in the feed. The same result was also shown by [23] who used rice straw as forage and concentrate with the same treatment ratio. This was due to the increased CP content with the increasing proportion of treated feed concentrate. In accordance with the results of previous studies [24, 25], protein will be easily fermented in the first 4-6 hours of incubation.

Based on the gas production data presented in Figure 1 the highest increase in gas production $\mathrm{s}$ shown at the $4^{\text {th }}$ hour for the PO and Madura cattle RF groups, and at the $6^{\text {th }}$ hour for the Bali cattle group with an average value range of $10-14 \mathrm{ml} / 500 \mathrm{mg} \mathrm{DM}$. This is because the main part of the protein will be fermented at the beginning of incubation along with other soluble components [26].

The potential of gas production shows a significant difference $(\mathrm{P}<0.05)$ only occurs in the feed treatment with RF storage time for 19 days as shown in Table 4. The highest potential of gas production value is shown in feed $\mathrm{C}$, while the highest gas production value is shown on feed A. The three feed treatments used contain high crude fibre but have the potential to be fermented by rumen microbes to produce gas [27]. Fibrous feed which has low digestibility will be broken down slowly because the digestion process is slow for the first time, so the enzyme action is delayed [28]. While the rate of gas production is directly proportional to total gas production, this is due to the fermentation of the protein contained in the feed that is generally easier to be fermented in the rumen and hence enhances the gas production during IVGP measurements.

The preservation of RF was carried out to determine the storage capacity of the RF so that it could be reused and facilitate the use of the inoculum from the same source in a series of studies. In Table 4. the two-day shelf life of the feed treatment gave the highest DMD value $(\mathrm{P}<0.01)$ compared to the storage time of 11 and 19 days. This decline in DMD may be attributable to the dehydrating effect of freezing and increment in storage time beginning at 11 and 19 days. This notion is supported by evidence reported by [12] where the adverse effect of freezing had been minimized by adding cryoprotectants such as glycerol and DMSO to the microbial medium (in this case: RF). It has been known that cryoprotectants act at the cell membrane level by limiting the dehydrating effect of cells during the freezing process, lowering the freezing point of extracellular and intracellular biological fluids, and encouraging the vitrification process rather than the formation of intracellular ice crystals $[29,30]$. Previous research [30] has proven that addition of $1 \%$ and $10 \%$ DMSO in the rumen ciliate cultures after being equilibrated at $25^{\circ} \mathrm{C}$ for 5 minutes has a low sensitivity to potential toxicity of DMSO. Another study [31] has used glycerol to compare lyophilized and frozen rumen microbes, showing that there is no effect of proteolytic activity on microbial preservation. Furthermore, [12] compared 5\% DMSO with 5\% glycerol as a cryoprotectant in RF, showing that the value of DMD was higher with DMSO-preserved RF than glycerol. However, recent research suggests that the addition of cryoprotectants to organic chemicals can cause toxicity effects such as DMSO and may interfere with subsequent in vitro testing because they are fermentable substrates (e.g. glycerol) [32]. Based on the negative effect of the addition of cryoprotectants, this study did not use cryoprotectants and refers to $[11,33,34]$. 
Table 3. The effect of treatment on observed variables

\begin{tabular}{|c|c|c|c|c|c|c|c|c|c|c|c|c|}
\hline \multirow{2}{*}{ Item } & \multicolumn{3}{|c|}{ PO Cattle } & \multicolumn{3}{|c|}{ Madura Cattle } & \multicolumn{3}{|c|}{ Bali Cattle } & \multirow{2}{*}{ SEM } & \multirow{2}{*}{$\begin{array}{c}\text { p-value } \\
\text { (PxLxS) }\end{array}$} & \multirow{2}{*}{ Sig. } \\
\hline & 2 days & 11 days & 19 days & 2 days & 11 days & 19 days & 2 days & 11 days & 19 days & & & \\
\hline \multicolumn{13}{|c|}{ Total of gas production ( $\mathrm{ml} / 500 \mathrm{mg} \mathrm{DM})$} \\
\hline A & 126.00 & 130.17 & 113.97 & 122.43 & 131.51 & 130.19 & 104.88 & 77.61 & 95.60 & \multirow{3}{*}{3.689} & \multirow{3}{*}{0.998} & \multirow{3}{*}{ ns } \\
\hline B & 113.30 & 120.17 & 102.91 & 114.18 & 124.30 & 126.04 & 101.65 & 65.71 & 90.21 & & & \\
\hline $\mathrm{C}$ & 110.87 & 110.68 & 92.38 & 102.87 & 105.93 & 116.30 & 88.72 & 59.96 & 87.03 & & & \\
\hline \multicolumn{13}{|c|}{ Potential of gas production (ml/500mg DM) } \\
\hline A & 139.39 & 132.03 & 126.69 & 145.21 & 147.91 & 144.01 & 122.28 & 105.17 & 112.63 & \multirow{3}{*}{16.059} & \multirow{3}{*}{0.798} & \multirow{3}{*}{ ns } \\
\hline $\mathrm{B}$ & 135.94 & 137.32 & 136.53 & 144.43 & 162.50 & 151.41 & 135.64 & 93.35 & 111.10 & & & \\
\hline $\mathrm{C}$ & 161.83 & 126.94 & 170.06 & 162.15 & 197.99 & 158.88 & 202.33 & 556.96 & 167.87 & & & \\
\hline \multicolumn{13}{|c|}{ Rate of gas production value (ml/hour) } \\
\hline $\mathrm{A}$ & 0.050 & 0.064 & 0.045 & 0.044 & 0.047 & 0.049 & 0.041 & 0.029 & 0.037 & \multirow{3}{*}{0.003} & \multirow{3}{*}{0.999} & \multirow{3}{*}{ ns } \\
\hline $\mathrm{B}$ & 0.039 & 0.052 & 0.028 & 0.035 & 0.030 & 0.038 & 0.030 & 0.027 & 0.033 & & & \\
\hline $\mathrm{C}$ & 0.025 & 0.041 & 0.016 & 0.022 & 0.016 & 0.027 & 0.012 & 0.002 & 0.015 & & & \\
\hline \multicolumn{13}{|c|}{ Rumen Dry matter degradability (\%) } \\
\hline A & 37.58 & 32.80 & 37.03 & 46.47 & 42.40 & 37.88 & 48.38 & 41.86 & 47.35 & \multirow{3}{*}{0.984} & \multirow{3}{*}{0.993} & \multirow{3}{*}{$\mathrm{ns}$} \\
\hline $\mathrm{B}$ & 40.70 & 33.79 & 31.91 & 45.63 & 44.52 & 43.43 & 42.95 & 38.25 & 42.37 & & & \\
\hline $\mathrm{C}$ & 35.51 & 34.87 & 29.03 & 46.47 & 42.33 & 45.17 & 42.11 & 37.68 & 40.38 & & & \\
\hline \multicolumn{13}{|c|}{ Rumen Organic matter degradability (\%) } \\
\hline A & 50.67 & 46.20 & 44.87 & 50.93 & 52.39 & 48.18 & 52.66 & 52.75 & 70.00 & \multirow{3}{*}{1.535} & \multirow{3}{*}{0.945} & \multirow{3}{*}{ ns } \\
\hline $\mathrm{B}$ & 49.08 & 43.93 & 43.62 & 50.34 & 61.23 & 49.28 & 48.41 & 40.98 & 64.79 & & & \\
\hline $\mathrm{C}$ & 42.24 & 42.05 & 48.16 & 43.45 & 49.95 & 47.49 & 45.34 & 42.18 & 70.53 & & & \\
\hline
\end{tabular}

A, B, C = feed treatments; SEM= Standard Error of the Mean; PxLxS= interaction of feed, storage time of rumen fluid, and inoculum source; Sig.= Significance ns) there was no significant different $(\mathrm{P}>0.05)$ in interaction of feed, storage time of rumen fluid, and inoculum source 
Table 4. Main effect of feeding regime on IVGP parameters due to different storage time

\begin{tabular}{|c|c|c|c|c|c|c|c|c|c|c|c|c|c|c|c|c|c|c|}
\hline \multirow{2}{*}{ Variable } & \multicolumn{3}{|c|}{2 Days Storage } & \multirow{2}{*}{ SEM } & \multirow{2}{*}{ p-value } & \multirow{2}{*}{ Sig. } & \multicolumn{3}{|c|}{11 Days Storage } & \multirow{2}{*}{ SEM } & \multirow{2}{*}{ p-value } & \multirow{2}{*}{ Sig. } & \multicolumn{3}{|c|}{19 Days Storage } & \multirow{2}{*}{ SEM } & \multirow{2}{*}{$\begin{array}{c}\text { p- } \\
\text { value }\end{array}$} & \multirow{2}{*}{ Sig. } \\
\hline & $\mathbf{A}$ & B & $\mathrm{C}$ & & & & A & B & C & & & & A & B & $\mathrm{C}$ & & & \\
\hline \multicolumn{19}{|c|}{ IVGP parameters } \\
\hline $\mathrm{Y}$ & $117.77^{\mathrm{b}}$ & $109.71^{\mathrm{ab}}$ & $100.82^{\mathrm{a}}$ & 3.794 & 0.007 & $* *$ & $128.04^{\mathrm{b}}$ & $121.51^{\mathrm{b}}$ & $108.37^{\mathrm{a}}$ & 3.399 & 0.004 & $* *$ & $113.25^{\mathrm{b}}$ & $106.38^{\mathrm{ab}}$ & $98.57^{\mathrm{a}}$ & 3.361 & 0.017 & * \\
\hline b & 135.62 & 138.67 & 175.44 & 7.786 & 0.097 & ns & 145.71 & 152.78 & 173.01 & 5.676 & 0.070 & ns & $127.78^{\mathrm{a}}$ & $133.01^{\mathrm{a}}$ & $165.60^{\mathrm{b}}$ & 7.375 & 0.049 & * \\
\hline $\mathrm{c}$ & $0.045^{\mathrm{c}}$ & $0.035^{\mathrm{b}}$ & $0.020^{\mathrm{a}}$ & 0.004 & 0.0002 & $* *$ & $0.047^{\circ}$ & $0.034^{\mathrm{b}}$ & $0.022^{\mathrm{a}}$ & 0.004 & 0.001 & $* *$ & $0.044^{c}$ & $0.033^{\mathrm{b}}$ & $0.019^{\mathrm{a}}$ & 0.004 & 0.003 & $* *$ \\
\hline \multicolumn{19}{|c|}{ Rumen degradability } \\
\hline DMD & 44.14 & 43.09 & 41.36 & 1.449 & 0.467 & ns & 42.25 & 44.53 & 44.65 & 0.907 & 0.439 & ns & 40.75 & 39.24 & 38.19 & 2.021 & 0.785 & ns \\
\hline OMD & $51.42^{\mathrm{b}}$ & $49.28^{\mathrm{b}}$ & $43.68^{\mathrm{a}}$ & 1.208 & 0.003 & $* *$ & 50.50 & 53.62 & 46.96 & 1.601 & 0.142 & ns & 54.35 & 52.56 & 55.40 & 3.669 & 0.390 & ns \\
\hline
\end{tabular}

Table 5. Main effect of feeding regime on IVGP parameters attributed to different inoculum source

\begin{tabular}{|c|c|c|c|c|c|c|c|c|c|c|c|c|c|c|c|c|c|c|}
\hline \multirow{2}{*}{ Variable } & \multicolumn{3}{|c|}{ PO Cattle } & \multirow{2}{*}{ SEM } & \multirow{2}{*}{$\begin{array}{c}\mathrm{p}- \\
\text { value }\end{array}$} & \multirow{2}{*}{ Sig. } & \multicolumn{3}{|c|}{ Madura Cattle } & \multirow{2}{*}{ SEM } & \multirow{2}{*}{$\begin{array}{c}\mathrm{p}- \\
\text { value }\end{array}$} & \multirow{2}{*}{ Sig. } & \multicolumn{3}{|c|}{ Bali Cattle } & \multirow{2}{*}{ SEM } & \multirow{2}{*}{ p-value } & \multirow{2}{*}{ Sig } \\
\hline & $\mathbf{A}$ & B & C & & & & $\mathbf{A}$ & B & C & & & & $\mathbf{A}$ & B & C & & & \\
\hline \multicolumn{19}{|c|}{ IVGP parameters } \\
\hline $\mathrm{Y}$ & $123.38^{\mathrm{b}}$ & $112.13^{\mathrm{a}}$ & $104.64^{\mathrm{a}}$ & 3.822 & 0.002 & $* *$ & $128.04^{\mathrm{b}}$ & $121.51^{\mathrm{b}}$ & $108.37^{\mathrm{a}}$ & 3.399 & 0.004 & $* *$ & $92.69^{\mathrm{b}}$ & $85.85^{\mathrm{ab}}$ & $78.57^{\mathrm{a}}$ & 5.109 & 0.018 & * \\
\hline b & 132.70 & 136.60 & 152.94 & 5.031 & 0.284 & ns & 145.71 & 152.78 & 173.01 & 5.676 & 0.070 & ns & 113.36 & 113.36 & 309.05 & 48.652 & 0.224 & ns \\
\hline $\mathrm{c}$ & $0.053^{\mathrm{c}}$ & $0.040^{\mathrm{b}}$ & $0.027^{\mathrm{a}}$ & 0.005 & 0.0002 & $* *$ & $0.047^{\mathrm{c}}$ & $0.034^{\mathrm{b}}$ & $0.022^{\mathrm{a}}$ & 0.004 & 0.001 & ** & $0.036^{b}$ & $0.030^{\mathrm{b}}$ & $0.010^{\mathrm{a}}$ & 0.004 & 0.0009 & ** \\
\hline \multicolumn{19}{|c|}{ Rumen degradability } \\
\hline DMD & 35.80 & 35.47 & 33.14 & 1.147 & 0.548 & ns & 42.25 & 44.53 & 44.65 & 0.907 & 0.439 & $\mathrm{~ns}$ & $45.86^{\mathrm{b}}$ & $41.19^{\mathrm{a}}$ & $40.06^{\mathrm{a}}$ & 1.205 & 0.002 & ** \\
\hline OMD & 47.25 & 45.54 & 44.15 & 1.027 & 0.575 & ns & 50.50 & 53.62 & 46.96 & 1.601 & 0.142 & ns & 58.47 & 51.39 & 52.68 & 3.845 & 0.122 & $\mathrm{~ns}$ \\
\hline
\end{tabular}

$\mathrm{Y}=$ total of gas production $(\mathrm{ml} / 500 \mathrm{mg} \mathrm{DM}) ; \mathrm{b}=$ potential of gas production $(\mathrm{ml} / 500 \mathrm{mg} \mathrm{DM}) ; \mathrm{c}=$ rate of gas production (ml/hour); DMD= Dry Matter Degradability $(\%)$; OMD= Organic Matter Degradability $(\%) ; \mathrm{A}, \mathrm{B}, \mathrm{C}=$ feeding regimes; $\mathrm{SEM}=$ Standard Error of the Mean; Sig.= Significance

Note: see Table 4 for notation explanation 
Table 6. Main effect of storage time on IVGP parameter among different inoculum source

\begin{tabular}{|c|c|c|c|c|c|c|c|c|c|c|c|c|c|c|c|c|c|c|}
\hline \multirow{2}{*}{ Variable } & \multicolumn{3}{|c|}{ PO Cattle } & \multirow{2}{*}{ SEM } & \multirow{2}{*}{ p-value } & \multirow{2}{*}{ Sig. } & \multicolumn{3}{|c|}{ Madura Cattle } & \multirow{2}{*}{ SEM } & \multirow{2}{*}{ p-value } & \multirow{2}{*}{ Sig. } & \multicolumn{3}{|c|}{ Bali Cattle } & \multirow{2}{*}{ SEM } & \multirow{2}{*}{ p-value } & \multirow{2}{*}{ Sig. } \\
\hline & 2 & 11 & 19 & & & & 2 & 11 & 19 & & & & 2 & 11 & 19 & & & \\
\hline \multicolumn{19}{|c|}{ IVGP parameters } \\
\hline Y & $116.72^{\mathrm{b}}$ & $120.34^{\mathrm{b}}$ & $103.09^{\mathrm{a}}$ & 3.822 & 0.002 & $* *$ & $113.16^{\mathrm{a}}$ & $120.58^{\mathrm{b}}$ & $124.18^{\mathrm{b}}$ & 3.399 & 0.030 & $*$ & 98.41 & 67.76 & 90.94 & 5.109 & 0.0009 & ns \\
\hline b & 145.72 & 132.10 & 144.43 & 5.031 & 0.490 & ns & 150.60 & 169.47 & 151.43 & 5.676 & 0.151 & ns & 153.41 & 251.82 & 130.53 & 48.652 & 0.539 & ns \\
\hline c & $0.038^{\mathrm{b}}$ & $0.052^{c}$ & $0.030^{\mathrm{a}}$ & 0.005 & 0.0003 & *** & 0.034 & 0.031 & 0.038 & 0.003 & 0.086 & ns & $0.028^{b}$ & $0.019^{\mathrm{a}}$ & $0.028^{\mathrm{b}}$ & 0.004 & 0.034 & * \\
\hline \multicolumn{19}{|c|}{ Rumen degradability } \\
\hline DMD & 37.93 & 33.82 & 32.66 & 1.147 & 0.192 & ns & 46.19 & 43.08 & 42.16 & 0.907 & 0.199 & ns & $44.48^{\mathrm{b}}$ & $39.26^{\mathrm{b}}$ & $43.36^{\mathrm{a}}$ & 1.205 & 0.005 & *** \\
\hline OMD & 50.50 & 53.62 & 46.96 & 1.601 & 0.116 & ns & 48.24 & 54.52 & 48.32 & 1.601 & 0.116 & ns & $48.80^{\mathrm{a}}$ & $45.30^{\mathrm{a}}$ & $68.44^{\mathrm{b}}$ & 3.845 & 0.002 & *** \\
\hline
\end{tabular}



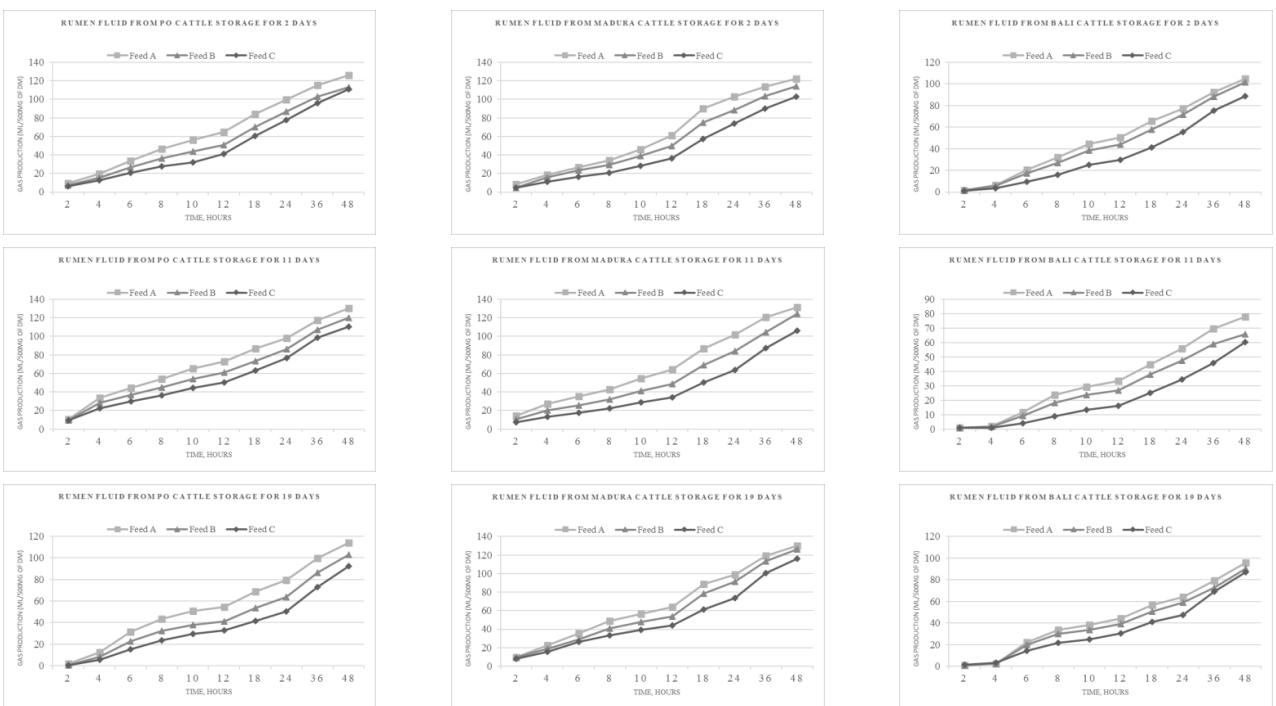

Fig. 1. Gas production patterns produced from different feeding regimes, microbial inoculum source and storage time of rumen fluid in the respective indigenous breed of cattle 


\section{Conclusion}

Based on the data obtained, this study supports the previous findings reported in the literature on the feasibility to use the frozen RF for IVGP measurement with the special attention should be considered, that is only using the RF from the same breed of cattle. Further studies may be warranted to evaluate the benefit of adding cryoprotectants during freezing process that render the detrimental effect of freezing and hence to improve longevity of microbes in the rumen to digest feed during IVGP measurements.

The authors wish to express our sincere gratitude for tangible help given by Rizka M.A., Aprilia D.K., Roi K.J., Muhammad R.A., Lisa M.M., Ainy, Hafidz, and Arya D.S. Thanks also due to the person in charge at each RF collection site, who made the collection and transportation of RF arrived promptly at our nutrition laboratory. We are indebted to the financial support provided by Brawijaya University through a special grant for professorship to HS that enabled the completion of this study.

\section{Reference}

1. M. Blümmel, E.R. Ørskov, Anim. Feed Sci. Technol. 40, 109-119 (1993)

2. M.S. Dhanoa, S. Lopez, J. Dijkstra, D.R. Davies, R. Sanderson, B.A. Williams, Z. Sileshi, J. France, B. J. N. 82, 131-142 (2000)

3. A.S. Chaudhry, R.A.I. Mohamed, Czech J. Anim. Sci. 57, 265-273 (2012)

4. M. Mutimura, C.B. Myambi, P. Gahunga, D.M. Mgheni, G.H. Laswai, L.A. Mtenga, D. Gahakwa, A.E. Kimambo, C. Ebong, Agric J. 8, 173-180 (2013)

5. S.E. Cavalcante, V.R. Vasconcelos, A.L. Abdalla, A.A. Alves, A.S. Natel, D. Shanasekaran, L.R.F. da Silva, J.C. Siqueira, Faecal inoculum as alternative microbial source for in vitro rumen fermentation techniques, in Proceeding of Conference on International Research on Food Security, Natural Resource Management and Rural Development, 16-18 September 2015, Berlin, Germany (2015)

6. J.W. Cone, A.H. van Gelder, H. Bachmann, Anim. Feed Sci. Technol. 99, 221-231 (2002)

7. C.S. Pandian, T.J. Reddy, K. Sivalah, M. Blümmel, Y.R. Reddy, Anim. Feed Sci. Technol. 16, 271-281 (2016)

8. G.T. Bergmann, B. M. C. Vet. Res. 13, 253 (2017)

9. T. Geishauser, A. Gitzel, S. R. R. 21, 63-69 (1996)

10. G.A. Beyihayo, R. Omaria, C. Namazzi, A. Atuhaire, U. G. A. S. 16, $93-98$ (2015)

11. A.S. Chaudhry, R.A.I. Mohamed. Czech J. Anim. Sci., 57, 2012 (6): 265-273

12. N. Denek, A. Can, M. Avei. S. A. J. A. S. 40, 251-256 (2010)

13. S.A. Nagadi, Met. Env. \& Arid Land Agric. Sci. 28, 27-36 (2019)

14. AOAC Official Method of Analysis. 18th Edition, Association of Officiating Analytical Chemists, Washington DC, Method 935.14 and 992.24. (2005)

15. H. Soetanto, R.M.Aprilia, M.S.Pramita and I.Banna. Comparison of Three Different Rumen Fluid As A Source of Inoculum To Evaluate In Vitro Gas Production And Digestibility of Elephant Grass-Concentrate Mixture ,In Proceedings of $2^{\text {nd }}$ International Conference On Animal Production For Food Sustainability, Organized by the University of Andalas and University of Udayana, held on June $16^{\text {th }}, 2021,(2021)$.

16. H.P.S. Makkar, M. Blümmel, K. Becker, B. J. N. 73, 897-913 (1995) 
17. M. Blümmel, H. Steingaß, K. Becker, B. J. N. 77, 911-921 (1997)

18. A. Sastrosupadi, Rancangan Percobaan Praktis Untuk Bidang Pertanian, Kanisius, Yogyakarta (1995)

19. E. Jami, A. Israel, A. Kotser, I. Mizrahi, The ISME J. 7, 1069-1079 (2013)

20. S. Wang, J. Pisarčíková, M. Kreuzer, A. Schwarm, Can. J. Anim. Sci. 1-30 (2018)

21. F. Li, C. Li, Y. Chen, J. Liu, C. Zhang, B. Irving, C. Fitzsimmons, G. Platstow, L.L. Guan, Microbiome, 7, 1-17 (2019)

22. T.A. McAllister, H.D. Bae, G.A. Jones, K.J. Cheng, J. Anim. Sci. 7, 303-316 (1994)

23. D.V. Dung, W. Shang, W. Yao, Asian Australas. J. Anim. 27, 797-805 (2014)

24. J.W. Cone, A.H. van Gelder, Anim. Feed Sci. Technol. 76, 251-264 (1999)

25. A. Karabulut, O. Canbolat, H. Kalkan, F. Gurbuzol, E. Sucu, I. Filya, Asian-Aust. J. Anim. Sci. 4, 517-522 (2007)

26. J.W. Cone, A.H. van Gelder, F. Driehuis, Anim. Feed Sci. Technol. 66, 31-45 (1997)

27. E.R. Ørskov, I. McDonald, J. Agric. Sci. 92, 499-503 (1979)

28. P. McDonald, R.A. Edwards, J.F.D. Greenhalgh, C.A. Morgan, Animal Nutrition, $7^{\text {th }}$ Edn, John Willey and Sons, New York, USA (2010)

29. P. Mazur, A.J.P. Cell 247, 125-142 (1984)

30. I. Tanasawa, Ann. N. Y. Acad. Sci. 858, 227-234 (1998)

31. E. Nsabimana, S. Kisidayova, D. Macheboeuf, C.J. Newbold, J.P. Jouany, Appl. Environ. Microbiol. 69, 3826-3832 (2003)

32. N.D. Luchini, G.A. Broderick, D.K. Combs, J. Anim. Sci. 74, 1134-1143 (1996)

33. A. Prates, J.A. de Oliveira, L. Abecia, M. Fondevila, Anim. Feed Sci. Technol. 155, 186193 (2010)

34. M. Spanghero, M. Chiaravalli, S. Colombini, C. Fabro, F. Froldi, F. Mason, M. Moschini, C.Sarnataro, S. Schiavon, F. Tagliapietra, Animals 9, 1-14 (2019) 